\title{
Studi Kepuasan Nasabah PT. Bank Negara Indonesia (Persero), Tbk Kantor Cabang Pembantu UPI Bandung
}

\author{
Dedy Ansari Harahap ${ }^{1}$, Dita Amanah ${ }^{2}$ \\ Fakultas Ekonomi, Universitas Islam Sumatera Utara \\ Fakultas Ekonomi, Universitas Negeri Medan \\ 1deanhar@yahoo.com, ${ }^{2}$ ditamnh@yahoo.com
}

\begin{abstract}
ABSTRAK
Relationship marketing merupakan strategi pemasaran yang bertujuan untuk membangun hubungan dengan nasabah yang harus diadopsi oleh industri perbankan. Tujuan penelitian ini untuk menentukan dampak pemasaran relasional melalui dimensi komitmen, empati dan timbal balik terhadap kepuasan nasabah. Pendekatan kuantitatif dengan tipe penelitian eksplanatori digunakan pada penelitian ini. Jumlah sampel sebanyak 90 responden yang dipilih secara acak dengan teknik sampel non probability sampling. Kuesioner digunakan sebagai instrumen untuk mengumpulkan data dengan skala Likert sebagai pengukurannya dan kemudian dianalisis dengan metode analisis regresi linier berganda. Penelitian ini menemukan bahwa dimensi pemasaran relasional memiliki dampak positif terhadap tingkat kepuasan nasabah. Nilai $\mathrm{R}_{2}$ yang dihasilkan adalah sebesar 0,469 atau 46,90\%. Artinya pengaruh variabel bebas (komitmen, empati dan timbal balik) terhadap variabel terikat (kepuasan nasabah) adalah sebesar $46,90 \%$ dan sisanya sebesar 53,10\% dipengaruhi oleh variabel lain di luar studi ini.
\end{abstract}

Kata Kunci: Komitmen, Empati, Timbal Balik, Kepuasan Nasabah, Bank

\section{ABSTRACT}

Relationship marketing is a marketing strategy that aims to build relationships between banks and customers that must be adopted by the banking industry. The purpose of this study is to determine the impact of relational marketing through the dimensions of commitment, empathy and reciprocity to customer satisfaction. The quantitative approach with the type of explanatory research was used in this study. The number of samples was 90 respondents who were randomly selected using non probability sampling techniques. The questionnaire was employed as an instrument to collect data with a Likert scale as a measurement and then analyzed by multiple linear regression analysis methods. This study found that the dimensions of relational marketing have a positive impact on the level of customer satisfaction. The value of $R_{2}$ produced is equal to 0.469 or $46.90 \%$. This means that the influence of independent variables (commitment, empathy and reciprocity) on the dependent variable (customer satisfaction) is $46.90 \%$ and the remaining $53.10 \%$ is influenced by other variables outside of this study.

Keywords: Commitment, Empathy, Reciprocity, Customer Satisfaction, Bank

\section{PENDAHULUAN}

Sektor perbankan merupakan industri jasa yang mengalami perkembangan dan persaingan yang cukup ketat seperti di Indonesia. Meningkatnya jumlah bank-bank yang berasal dari luar negeri menyebabkan tingkat persaingan perbankan nasional atau lokal menjadi lebih besar sehingga bukan hanya bersaing dengan bank lokal saja tetapi juga bersaing dengan bank yang besar yang berasal dari luar negeri. Berdasarkan situasi dan kondisi tersebut maka prospek perkembangan perbankan akan semakin kompleks dalam menjawab tuntutan yang ada.

ISSN: 1829-8680 E-ISSN: 2599-0039 
Menciptakan dan mempertahankan nasabah harus dilakukan pada dunia perbankan untuk mencapai keberhasilan dalam persaingan. Masyarakat semakin memperhatikan perkembangan dan peningkatan jasa pelayanan perbankan sehingga mengakibatkan semakin ketatnya persaingan diantara perusahaan perbankan yang semakin tumbuh. Salah satu strategi yang bisa diterapkan untuk mempertahankan konsumen dan bisa menjadi pelanggan tetap adalah dilakukannya strategi pemasaran relasional.

Terdapat tiga pendekatan yang bisa dilakukan oleh bank dalam penelitian ini untuk menjaga dan mengembangkan hubungan dengan pelanggan yang terdiri dari komitmen (comitment), empati (empathy), dan timbal balik (reciprocity). Ketiga pendekatan ini berhubungan satu sama lain dan terkait yang dapat menyebabkan hubungan bank yang lebih erat dengan nasabah sehingga terwujud ikatan kekeluargaan.

Pada bidang pemasaran jasa dan industri telah muncul konsep relationship marketing yang didukung kuat oleh tren bisnis modern yang terjadi secara berkelanjutan. Relationship marketing merupakan konsep pemasaran untuk menetapkan, mempertahankan dan meningkatkan hubungan antara perusahaan dengan pelanggan sehingga terpenuhi tujuan perusahaan dan juga pelanggan pada tingkat yang menguntungkan (Grönroos, 1994).

\section{LANDASAN TEORI DAN HIPOTESIS}

Relationship marketing adalah bentuk pemasaran yang ditinjau sebagai hubungan, jaringan dan interaksi (Gummesson, 1997). Hubungan diartikan sebagai kontak antara dua orang atau lebih, antara orang dengan objek dan juga antara simbol dengan organisasi. Jaringan merupakan himpunan dari hubungan sementara interaksi terkait dengan kegiatan yang dilakukan dalam hubungan dan jaringan. Jadi konsumen yang coba mengenal secara lebih dekat dengan perusahaan dimana tercipta komunikasi diantara mereka dan menata hubungan yang saling menguntungkan antara perusahaan dengan konsumen disebut relationship marketing (Chan, 2003). Pendapat lain menyatakan bahwa iklan, hubungan masyarakat, promosi penjualan, pemasaran langsung adalah gabungan elemen relationship marketing yang bertujuan untuk menciptakan cara yang lebih efektif dan efisien dalam memperoleh pelanggan (Copulsky \& Wolf,1990).

Pemasaran relasional memiliki peranan penting dalam menciptakan kepuasan nasabah. Menurut Zeithaml, Bitner, \& Gremler, (2017), "Upaya suatu bank untuk mengenal nasabah dengan lebih baik sehingga kebutuhan dan keinginan nasabah dapat dipenuhi oleh bank dalam jangka panjang merupakan makna dari relationship marketing". Pemenuhan kebutuhan dan keingan tersebut selanjutnya akan menciptakan kepuasan nasabah. Oleh sebab itu, setiap bank harus selalu dapat meningkatkan pemasaran relasional supaya nasabah mendapatkan kepuasan dan terus menjalin hubungan jangka panjang dengan bank yang tentu secara positif menguntungkan bagi bank.

Konsep pemasaran relasional telah lama dan cukup besar menjadi pusat perhatian penelitian dari para ahli pemasaran selama dua dekade terakhir (Berry, 2002; Grönroos, 1994; Morgan \& Hunt, 1994; Sheth \& Parvatiyar, 1995; Vargo, 2009). Pemasaran relasional mempunyai tujuan utama membangun dan mempertahankan pelanggan yang memiliki komitmen serta memberi keuntungan bagi bank dan sekaligus memperkecil usaha dan waktu bank untuk nasabah yag dianggap kurang menguntungkan (Zeithaml \& Bitner, 2003). 
Komitmen merupakan kondisi psikologis yang secara menyeluruh merupakan representasi pengalaman ketergantungan pada suatu hubungan. Indikator komitmen adalah memiliki ikatan emosional, rasa memiliki dan hubungan penting untuk dipertahankan (Barnes, 2003). Empati adalah kesanggupan perusahaan untuk memahami kesulitan yang dihadapi pelanggan, memberi perhatian secara personal kepada pelanggan, jam operasional yang nyaman (Tjiptono, 2008). Sedangkan timbak balik yaitu unsur dari hubungan bisnis yang mencerminkan kerelaan masing-masing pihak untuk sama-sama memerlukan dan memberikan kembali kebaikan kepada pihak lain yang telah memberikan kebaikan (Sin, Tse, \& Yim, 2005).

Dari definisi diatas dapat disimpulkan menurut penulis bahwa pemasaran relasional pada perspektif bank adalah cara atau upaya yang dilakukan untuk menjalin hubungan jangka panjang antara bank dengan nasabahnya, yaitu dengan memenuhi kebutuhan dan keinginan nasabah dalam jangka panjang. Mencapai kesuksesan pemasaran dengan membina dan mempertahankan relasi dengan nasabah secara berkelanjutan merupakan paradigma baru yang perlu dibentuk oleh setiap bank. Landasan berfikir penerapan pemasaran ini adalah relasi dengan nasabah diduga sangat menghemat biaya daripada melakukan pencarian nasabah baru atau mencari kembali nasabah lama yang sudah lama tidak berhubungan dengan bank atau pindah ke bank lain.

Keseluruhan sikap konsumen terhadap barang atau jasa yang telah dikonsumsi merupakan definisi kepuasan pelanggan (Donavan, Minor, \& Mowen, 2016). Konsep ini telah ada dalam berbagai kerangka kerja, konseptual dan model teoritis penelitian (Chan, 2003). Model-model atau kerangka kerja ini telah membahas pengukuran kepuasan pelanggan, driver kepuasan pelanggan, serta pengukuran variabel terkait (Keillor, Parker, \& Pettijohn, 1999). Kepuasan pelanggan dicapai melalui pengalaman pelanggan dengan produk/layanan dibandingkan dengan harapan. Kepuasan pelanggan telah didefinisikan dalam berbagai cara yaitu: perasaan keseluruhan, atau sikap, seseorang memiliki tentang suatu produk setelah dibeli (Solomon, 2009), atau sebagai ringkasan, respon intensitas afektif dan variabel yang fokus pada aspek khusus perolehan dan/atau penggunaan barang atau jasa yang terjadi pada saat yang tepat saat konsumen mengevaluasi suatu objek (Giese \& Cote, 2002).

Kepuasan pelanggan dipandang sebagai penilaian pelanggan secara menyeluruh terhadap kinerja penawaran yang dilakukan perusahaan hingga konsumsi yang dilakukan pelanggan (Johnson \& Fornell, 1991). Evaluasi keseluruhan ini sangat tergantung pada kinerja organisasi dan produk. Namun, kinerja untuk sebagian besar tergantung pada hubungan pemasaran jangka panjang yang ramah antara pelanggan dan organisasi.

Beberapa pengertian diatas mengarahkan penulis untuk berasumsi bahwa kepuasan pelanggan (nasabah) dalam perspektif bank adalah sebagai suatu komparasi antara pelayanan yang diberikan bank dengan hasil pelayanan yang diterima nasabah. Pelayanan tersebut harus sama dengan harapan nasabah atau bahkan melebihi. Pada dasarnya nasabah mengharapkan dapat memperoleh produk yang memiliki manfaat. Setiap nasabah akan mengalami berbagai tingkat kepuasan dan bahkan ketidakpuasan atas pelayanan yang diberikan dan sekaligus menilai sejauh mana harapan mereka terpenuhi atau bahkan terlampaui. Pada dasarnya setiap pelanggan menginginkan produk yang memiliki manfaat dengan harga yang terjangkau. Oleh sebab itu bank harus berusaha secara optimal untuk mewujudkan keinginan nasabah dengan

ISSN: 1829-8680 E-ISSN: 2599-0039 
memanfaatkan seluruh aset dan kemampuan yang ada pada bank sehingga dapat memberi nilai dan memenuhi harapan nasabah.

\section{Pemasaran Relasional}

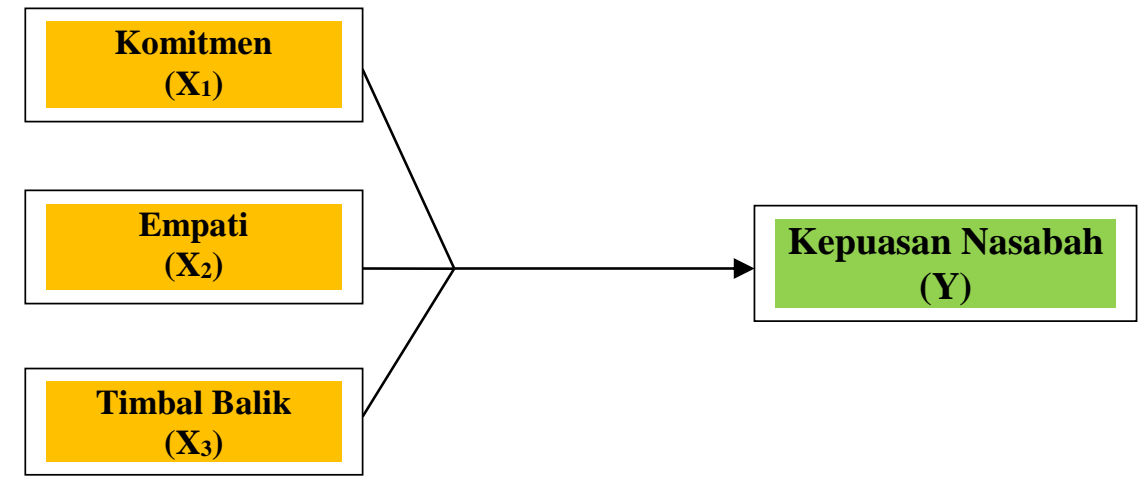

\section{Gambar 1. Kerangka Konseptual}

Sumber: Hasil Pengolahan Data

\section{Hipotesis}

Hipotesis ini menggambarkan hubungan antara variabel dalam konseptual kerangka kerja yang pada Gambar 1. Hipotesis yang diuraikan dalam penelitian ini adalah (H1) :Terdapat pengaruh Komitmen terhadap Kepuasan Nasabah, (H2) :Terdapat pengaruh Empati terhadap Kepuasan Nasabah, (H3):Terdapat pengaruh Timbal Balik terhadap Kepuasan Nasabah, (H4):Terdapat pengaruh Komitmen, Empati dan Timbal Balik terhadap Kepuasan Nasabah

\section{METODE PENELITIAN}

Pada penelitian ini kuesioner disebar kepada mahasiswa untuk memperoleh data primer yang diperlukan. Mereka adalah yang pernah bertransaksi di KCP BNI UPI Bandung. Sejumlah pertanyaan mengenai pemasaran relasional dieksplorasi, yang memiliki dimensi antara lain komitmen, empati, timbal balik yang terkait dengan kepuasan nasabah. Setiap responden menjawab kuesioner yang dipilih dengan memberikan peringkat alternatif pada setiap pilihan yang ditentukan. Pertanyaan diukur dengan skala Likert lima poin, dengan ketentuan adalah: 1 (sangat tidak setuju), 2 (tidak setuju), 3 (kurang setuju), 4 (setuju), 5 (sangat setuju).

Populasi penelitian ini adalah semua mahasiswa pascasarjana UPI yang pernah bertransaksi di KCP BNI UPI Bandung. Untuk mendapatkan teknik sampel yang tepat, non probability sampling dipilih sebagai teknik sampling yang lebih sesuai untuk tujuan penelitian ini. Responden dipilih secara acak dari mahasiswa pasca sarjana UPI yang datang ke bank. Dari 100 kuesioner dibagikan, hanya 90 yang dapat digunakan untuk dianalisis. Teknik pengumpulan data dengan menyebarkan kuesioner terkait pemasaran relasional terhadap kepuasan nasabah.

Peneliti menggunakan pendekatan kuantitatif dengan eksplanatori sebagai jenis penelitian. Analisis regresi linier berganda dilakukan untuk menguji pengaruh antara variabel 
independen (komitmen, empati, timbal balik) dengan variabel dependen (kepuasan nasabah) yang terdappat pada hipotesis 1-4.

\section{PEMBAHASAN}

\section{Analisis Regresi Berganda}

Model persamaan regresi dengan variabel terikat kepuasan nasabah (Y) dan variabel bebas yaitu komitmen $\left(\mathrm{X}_{1}\right)$, Empati $\left(\mathrm{X}_{2}\right)$ dan timbal balik $\left(\mathrm{X}_{3}\right)$ adalah :

$$
\mathbf{Y}=\mathbf{a}+\mathbf{b}_{1} \mathbf{X}_{1}+\mathbf{b}_{2} \mathbf{X}_{2}+\mathbf{b}_{3} \mathbf{X}_{3}+\mathbf{e}
$$

Tabel 1. Regresi Linear Berganda

\begin{tabular}{|c|c|c|c|c|c|c|c|c|}
\hline & \multirow[b]{2}{*}{ Model } & \multicolumn{3}{|c|}{ d $\begin{array}{c}\text { Coefficients }^{\mathbf{a}} \\
\text { Standardized } \\
\text { Coefficients }\end{array}$} & \multirow[b]{2}{*}{ t } & \multirow[b]{2}{*}{ Sig. } & \multicolumn{2}{|c|}{$\begin{array}{c}\text { Collinearity } \\
\text { Statistics }\end{array}$} \\
\hline & & B & $\begin{array}{r}\text { Std. } \\
\text { Error }\end{array}$ & Beta & & & Tolerance & VIF \\
\hline 1 & (Constant) & .749 & .422 & & 1.175 & .079 & & \\
\hline & Komitmen & .395 & .117 & .336 & 3.363 & .001 & .618 & 1.619 \\
\hline & Empati & .149 & .081 & .163 & 1.849 & .068 & .797 & 1.254 \\
\hline & $\begin{array}{l}\text { Timbal } \\
\text { Balik }\end{array}$ & .300 & .090 & .333 & 3.346 & .001 & .624 & 1.601 \\
\hline
\end{tabular}

a. Dependent Variable: Kepuasan Nasabah

Sumber: Hasil Pengolahan Data

Dari hasil pengolahan data, maka diperoleh persamaan regresi sebagai berikut :

$$
Y=0,749+0,395 X_{1}+0,149 X_{2}+0,300 X_{3}+e
$$

Keterangan :

$\mathrm{Y}=$ Kepuasan Nasabah, $\mathrm{X}_{1}=$ Komitmen, $\mathrm{X}_{2}=$ Empati, $\mathrm{X}_{3}=$ Timbal Balik

Konstanta $(\alpha)$ sebesar 0,749 menyatakan bahwa jika tidak ada variabel X maka kepuasan nasabah adalah 0,749 (asumsi faktor lain konstan). Koefisien regresi $\mathrm{X}_{1}$ sebesar 0,395 menyatakan bahwa setiap terjadi perubahan komitmen $1 \%$ akan mempengaruhi kepuasan nasabah (asumsi faktor lain konstan). Koefisien regresi $\mathrm{X}_{2}$ sebesar 0,149 menyatakan bahwa setiap terjadi perubahan empati $1 \%$ akan mempengaruhi kepuasan nasabah (asumsi faktor lain konstan). Koefisien regresi $\mathrm{X}_{3}$ sebesar 0,300 menyatakan bahwa setiap terjadi perubahan timbal balik $1 \%$ akan mempengaruhi kepuasan nasabah (asumsi faktor lain konstan).

\section{Uji Signifikansi Parsial (Uji t)}

Uji t pada penelitian ini adalah untuk melihat besarnya pengaruh antara variabel independen (komitmen, empati dan timbal balik) terhadap variabel dependen (kepuasan nasabah) secara parsial, adapun hasil Uji t dapat dilihat pada tabel 2 uji t. Untuk memperoleh besarnya t-tabel dilakukan perhitungan sebagai berikut: Taraf signifikansi $95 \%$ dan alpha $5 \%$, 
serta derajat kebebasan $(\mathrm{dk})$ dengan ketentuan $\mathrm{df}=\mathrm{n}-\mathrm{k}-1$ pada penelitian ini $(\mathrm{df}=90-3-1=$ 86).

Kriteria uji hipotesis adalah sebagai berikut : Jika t-hitung > t-tabel, Hol ditolak dan Ha1 diterima. Jika t-hitung < t-tabel, Ho1 diterima dan Ha1 ditolak.

Tabel 2. Hasil Uji t

\begin{tabular}{lcc}
\hline & \multicolumn{2}{c}{ Uji t } \\
\cline { 2 - 3 } Model & t Hitung & t Tabel \\
\hline (Constant) & 1.775 & 1.663 \\
Komitmen & 3.363 & 1.663 \\
Empati & 1.849 & 1.663 \\
Timbal Balik & 3.346 & 1.663 \\
\hline
\end{tabular}

Sumber: Hasil Pengolahan Data

(a). Pengujian pengaruh variabel Komitmen $\left(\mathbf{X}_{1}\right)$ terhadap Kepuasan Nasabah (Y) Berdasarkan tabel coefficients, diperoleh hasil 3,363 > 1,663, maka $\mathrm{H}_{01}$ ditolak dan $\mathrm{Ha} 1$ diterima. Hal ini berarti hipotesis diterima yaitu komitmen secara parsial (individu) positif berpengaruh secara signifikan terhadap kepuasan nasabah. (b). Pengujian pengaruh variabel Empati ( $\left.\mathbf{X}_{2}\right)$ terhadap Kepuasan Nasabah (Y) Berdasarkan tabel coefficients, diperoleh hasil 1,849>1,663, maka $\mathrm{H}_{01}$ ditolak dan $\mathrm{H}_{\mathrm{a} 1}$ diterima. Hal ini berarti hipotesis diterima yaitu empati secara parsial (individu) positif berpengaruh secara signifikan terhadap kepuasan nasabah. (c). Pengujian pengaruh variabel Timbal Balik $\left(\mathbf{X}_{3}\right)$ terhadap Kepuasan Nasabah (Y) Berdasarkan tabel coefficients, diperoleh hasil 3,346 > 1,663, maka $\mathrm{H}_{01}$ ditolak dan $\mathrm{H}_{\mathrm{a} 1}$ diterima. Hal ini berarti hipotesis diterima yaitu timbal balik secara parsial (individu) positif berpengaruh secara signifikan terhadap kepuasan nasabah.

\section{Uji Signifikansi Simultan (Uji F)}

\begin{tabular}{|c|c|c|c|c|c|c|}
\hline \multicolumn{7}{|c|}{ ANOVA $^{a}$} \\
\hline & Model & $\begin{array}{c}\text { Sum of } \\
\text { Squares }\end{array}$ & df & Mean Square & $\mathbf{F}$ & Sig. \\
\hline \multirow[t]{3}{*}{1} & Regression & 9.155 & 3 & 3.052 & 25.326 & $.000^{\mathrm{b}}$ \\
\hline & Residual & 10.363 & 86 & .120 & & \\
\hline & Total & 19.518 & 89 & & & \\
\hline
\end{tabular}

a. Dependent Variable: Kepuasan Nasabah

b. Predictors: (Constant), Komitmen, Empati, Timbal Balik

Sumber: Hasil Pengolahan Data

Pengujian hipotesis dilakukan dengan cara membandingkan besarnya angka $\mathrm{F}$ penelitian dengan F-tabel, dengan kriteria sebagai berikut: Jika $\mathrm{F}$-hitung $>\mathrm{F}$-tabel, maka $\mathrm{H}_{0}$ ditolak dan $\mathrm{H}_{\mathrm{a}}$ diterima dan Jika $\mathrm{F}_{\text {-hitung }}<\mathrm{F}$-tabel, maka $\mathrm{H}_{0}$ diterima dan $\mathrm{H}_{\mathrm{a}}$ ditolak

\section{Pengujian pengaruh variabel Komitmen $\left(X_{1}\right)$, Empati $\left(X_{2}\right)$ dan Timbal Balik $\left(X_{3}\right)$ terhadap Kepuasan Nasabah (Y)}

Berdasarkan Tabel 3, diperoleh nilai $F$ sebesar 25,326. Sedangkan nilai $F_{\text {tabel }}$ yang dihitung dengan rumus $\mathrm{df}_{1}=\mathrm{k}-1 ; \mathrm{df}_{2}=\mathrm{n}-\mathrm{k}-1(3 ; 86)$ adalah 2,71. Dengan demikian diperoleh nilai $F_{\text {hitung }}=25,326$ dan $F_{\text {tabel }}=2,71$. Karena $F_{\text {hitung }}>F_{\text {tabel }}$ yang berarti bahwa $\mathrm{H}_{0}$ ditolak dan 
Ha diterima, sehingga dapat disimpulkan bahwa komitmen, empati dan timbal balik berpengaruh positif dan signifikan terhadap kepuasan nasabah.

\section{Koefisien Determinasi}

Tabel 4. Koefisien Determinasi $\left(\mathbf{R}^{2}\right)$

\begin{tabular}{cccc} 
Model & $\mathbf{R}$ & $\boldsymbol{R}$ Square & Adjusted $\boldsymbol{R}$ Square \\
\hline 1 & $.685^{\mathrm{a}}$ & .469 & .451 \\
\hline Sumber: Hasil Pengolahan Data
\end{tabular}

Tabel 4. menunjukkan bahwa nilai $\mathrm{R}^{2}$ yang dihasilkan adalah sebesar 0,469 atau 46,90\%. Artinya pengaruh variabel bebas (komitmen, empati dan timbal balik) terhadap variabel terikat (kepuasan nasabah) adalah sebesar $46,90 \%$ dan sisanya sebesar $53,10 \%$ dipengaruhi oleh variabel lain di luar studi ini.

Secara parsial masing-masing variabel (komitmen, empati dan timbal balik) berpengaruh positif dan signifikan terhadap kepuasan nasabah di BNI KCP UPI Bandung. Sedangkan secara simultan pemasaran relasional (relationship marketing) yang terdiri dari komitmen, empati dan timbal balik secara bersama-sama berpengaruh positif dan signifikan terhadap kepuasan nasabah.

Disimpulkan bahwa kepuasan nasabah di BNI UPI Bandung dipengaruhi oleh pemasaran relasional yang dilakukan oleh bank. Menunjukkan bahwa strategi pemasaran yang diterapkan melalui pemasaran relasional melalui dimensi komitmen, empati dan timbal balik, mampu memberikan kepuasan terhadap nasabahnya. Strategi pemasaran yang telah dilakukan bank membuat nasabah merasa puas dan semakin percaya dan menjadi yakin terhadap relasi yang diciptkan bank dengan nasabahnya. Hasil ini didukung oleh (Sefesiyani, DH, \& Arifin, 2015; Utami, 2013), (Rini \& Absah, 2016) dan (Rini \& Absah, 2016).

Dalam tulisan lain yang menyelidiki hubungan pemasaran relasional dengan kepuasan nasabah dan kesetiaan nasabah Ghavamin Bank di Sistan dan provinsi Baluchistan. Hasil menunjukkan adanya hubungan positif dan signifikan antara dimensi pemasaran hubungan dengan kepuasan dan loyalitas pelanggan (Sayed \& Moghadam, 2015). Menurut Ibojo \& Dunmade, (2016) dalam penelitiannya menemukan bahwa pemasaran relasional mempengaruhi kepuasan konsumen untuk sebagian besar. Oleh karena itu diperlukan sektor keuangan dan non keuangan untuk merangkul dan memasukkan pemasaran hubungan dalam portofolio manajemen mereka

Oleh karena itu bank BNI harus selalu mengevaluasi setiap saat strategi pemasarannya salah satunya melalui pemasaran relasional, agar berjalan dengan baik dan efektif dalam membangun hubungan baik jangka panjang dalam upaya menciptakan kepuasan nasabah.

\section{KESIMPULAN}

Masing-masing variabel (komitmen, empati dan timbal balik) secara parsial berpengaruh positif dan signifikan terhadap kepuasan nasabah di BNI KCP UPI Bandung. Sedangkan secara simultan pemasaran hubungan yang terdiri dari dimensi komitmen, empati,

ISSN: 1829-8680 E-ISSN: 2599-0039 
timbal balik secara bersama-sama positif berpengaruh secara signifikan terhadap kepuasan nasabah di BNI KCP UPI Bandung. Bank dapat mengetahui sejauh mana pemasaran relasional yang telah dijalankan kepada nasabah, bank dapat mengidentifikasi faktor-faktor yang membuat nasabah merasa puas, sehingga bank dapat mempertahankan capaian yang baik dan meningkatkan apa saja yang masih kurang dari penilaian nasabah yang menggunakan jasanya di masa depan.

Sampel pada penelitian ini tidak memadai karena hanya terbatas pada mahasiswa yang bertransaksi di BNI KCP UPI Bandung. Jumlah sampel yang tidak mencukupi dianggap tidak representatif. Jumlah sampel perlu diperbesar untuk memberikan hasil yang lebih akurat. Perlu memperluas sampel tidak hanya di satu bank tetapi dari berbagai bank, sehingga hasil yang diharapkan dapat digeneralisasikan.

\section{DAFTAR PUSTAKA}

Barnes, J. G. (2003). Secrets Of Customer Relationship Management (Rahasia Manajemen Hubungan Pelanggan) (Edisi 2). Yogyakarta: Andi.

Berry, L. L. (2002). Relationship marketing of services perpectives from 1983 and 2000. Journal of Relationship Marketing, 1(1), 59-77. https://doi.org/10.1300/J366v01n01

Chan, S. (2003). Relationship Marketing. Jakarta: PT.Gramedia Pustaka Utama.

Copulsky, J. R., \& Wolf, M. J. (1990). Relationship Marketing: Positioning for the Future. Journal of Business Strategy, 11(4), 16-20.

Donavan, T., Minor, M. S., \& Mowen, J. C. (2016). Consumer Behavior. Chicago: Business Press.

Giese, J. L., \& Cote, J. A. (2002). Defining Customer Satisfaction. Marketing Science Review, 2000(1), 1-24. https://doi.org/10.1111/j.1365-2850.2008.01371.x

Grönroos, C. (1994). From Marketing Mix to Relationship Marketing: Towards a Paradigm Shift in Marketing. Management Decision, 32(2), 4-20. https://doi.org/10.1080/106351501753462849

Gummesson, E. (1997). Relationship marketing as a paradigm shift : Some conclusions from the 30R approach. Management Decision, 35(4), 267-272. https://doi.org/10.1108/00251749710169648

Ibojo, B. O., \& Dunmade, E. O. (2016). Impact of relationship marketing on customer satisfaction: a case study of undergraduate students in a private university, Oyo state, Nigeria. International Journal of Economics, Commerce and Management, 4(2), 668-

ISSN: 1829-8680 E-ISSN: 2599-0039 


\section{Jurnal Manajemen dan Bisnis: Performa Vol.16, No. 1 Maret 2019}

708. https://doi.org/http://dx.doi.org/10.1016/S1090-3798\%2811\%2970225-2

Johnson, M. D., \& Fornell, C. (1991). A Framework for Comparing Customer Satisfaction across Individuals and Product Categories. Journal of Economic Psychology, 12(2), 267-286.

Keillor, B. D., Parker, R. S., \& Pettijohn, C. E. (1999). Sales force performance satisfaction and aspects of relational selling: Implications for sales managers. Journal of Marketing Theory and Practice, 7(1), 101-115. https://doi.org/10.1080/10696679.1999.11501824

Morgan, R. M., \& Hunt, S. D. (1994). Theory of Relationship Marketing. Journal of Marketing, 58(3), 20-38.

Rini, E. S., \& Absah, Y. (2016). Analisis Pengaruh Pemasaran Relasional Terhadap Loyalitas Melalui Kepuasan Nasabah Tabungan Martabe Bank SUMUT di Kota Medan. In Conference on Management and Behavioral Studies (pp. 445-456). Jakarta: Universitas Tarumanagara.

Sayed, E. N., \& Moghadam, K. S. (2015). The Study of Relationship Marketing with Customer Satisfaction and Loyalty (Case Study: Customers of Ghavamin Bank in Sistan and Baluchestan Province). International Journal of Innovation and Research in Educational Sciences, 2(2), 96-101.

Sefesiyani, A., DH, A. F., \& Arifin, Z. (2015). Pengaruh Relationship Marketing (Pemasaran Relasional) Terhadap Kepuasan Nasabah Serta Dampaknya Pada Loyalitas Nasabah. Jurnal Administrasi Bisnis (JAB), 28(2), 1-8.

Sheth, J. N., \& Parvatiyar, A. (1995). The Future of Relationship Marketing. International Business Review, 4(4), 397-418. https://doi.org/10.1108/08876040210447324

Sin, L. Y. M., Tse, A. C. B., \& Yim, F. H. K. (2005). CRM conceptualization and scale development. European Journal of Marketing, 39(11), 1264-1290.

Solomon, M. R. (2009). Marketing : Real People, Real Decisions. Prentice Hall.

Tjiptono, F. (2008). Strategi Bisnis Pemasaran. Yogyakarta: Andi.

Utami, S. S. (2013). Analisis Pengaruh Trust Dan Commitment Terhadap Kepuasan Dan Loyalitas Pelanggan CV. Sumber Jaya Sakti Tarakan. Jurnal Manajemen Pemasaran, 1(2), 1-9.

Vargo, S. L. (2009). Toward a transcending conceptualization of relationship: A servicedominant logic perspective. Journal of Business and Industrial Marketing, 24(5), 373379. https://doi.org/10.1108/08858620910966255

Zeithaml, V. A., \& Bitner, M. J. (2003). Services Marketing: Integrating Customer Focus Across the Firm. McGraw-Hill/Irwin.

Zeithaml, V. A., Bitner, M. J., \& Gremler, D. (2017). Services Marketing: Integrating 
Jurnal Manajemen dan Bisnis: Performa Vol.16, No. 1 Maret 2019

Customer Focus Across the Firm (7th Editio). New York: McGraw-Hill Education.

\{Bibliography $\}$

ISSN: 1829-8680 E-ISSN: 2599-0039 